第 7 回学術集会会長講演

\title{
助産婦の行う性教育 Sexuality Education by Midwifery
}

\author{
浅 生 慶 子 (Keiko ASŌ) * \\ 第 7 回日本助産学会学術集会会長
}

\section{はじめに}

最近性教育の必要性について，いろいろな立場 の人が論じています。「性器と性交を教えなければ 性教育はできない」という積極派から，「動物は， 子どもに性に関することは教えないが自然に覚え る」, すなわち, 寝た子を起こすなという消極派ま でさまざまです。これらの性教育論争を見聞きし ていると, 現代日本人の性教育観は, まだまだ性 器教育や純潔教育が強調されているように思いま す。

このような状況の中で，1992年から，文部省の 学習指導要領に関する内容が変わり, 小学校 5 年 生の理科と保健の教科書に性教育が登場しまし た。小学校においては, 性教育元年としていろい ろな取り組みが始まっています。しかし，教師の 中には，何をどのように教えたらよいのか戸惑い がみられます。教える側の「性教育とは何か」と いう意識が, 年代あるいは個人によって著しく異 なっている感を強くもちます。つまり，共通認識 の上に立っての性教育がなされていないように思 います。これは, 今後の大きな課題ではないでし ようか。

それでは，助産婦はどんな性教育ができるので しょうか。助産婦の特殊性を生かした性教育のあ り方を模索しつつ進めてきました「私の考える性 教育」の一端をご紹介して, その責任を果たした いと思います。

\section{I 助産婦の行う性教育の特徵}

助産婦の行う性教育の特徴はどんなものでしょ うか。私は，以下，2つのことを挙げてみたいと 思います。

1つは, 人がこの世に誕生したとき, 最初に出 会う立場から，生命誕生の場面を感動的に伝える ことができること。また, 胎児期から父母とのか かわりをもってきた助産婦は，あなたの誕生を父 や母がどんなに期待し，大切に育ててきたかをド ラマチックに語ることができます。自分の誕生の 話を聞くときの子どもたちの輝いた目は，年秢や 男女を問わず印象深いものです。

2 つ目は, 助産婦の尃門性を生かした教育がで きることです。助産婦教育のカリキュラムは, 助 産婦は人のライフサイクルにわたり，性と生殖に かかわる専門職であるとの立場を明らかにしてい ます。その専門性を生かした展開ができます。し かも，対象は人のライフサイクル全般にわたるも のです。助産婦は，時代の変化に適応した専門性 を生かした性教育プログラムを構成することがで きます。

\section{II 私の行っている性教育}

最近, 小・中・高校や老人クラブ等からの講演 依頼を受け，話す機会が多くなりました。助産婦 としてはないへんうれしいことです。以下，対象 別に私の実践している内容を述べてみたいと思い

*九州大学医療技術短期大学部尃攻科助産学特別尃攻 (School of Medical Sciences, The University of Kyushu) 
ます。

\section{1. 小学生に対する指望内容}

小学生の対象は, ほとんどの学校が $5 \cdot 6$ 年生 です。内容は表 1 に示しました。時間は40～50分 で, 時期は, 夏休み前または, 修学旅行前が最も 多いようです。問題点としては，1.子どもたちの 背景がわからない，2.どのような教材を使えば効 果的かがわからない, などがおもなものです。事 前に養護教諭から知識の程度や身体の発育状況に ついて，情報を提供していただく場合もあります が, 多くは情報をもたないで行っています。市 部, 郡部で子どもたちは, まったく異なる反応を 示すことがあります。また，学校では一度に 5 ・ 6 年生に学習をさせることの効率性を考えての計 画と聞きますが，できれば成長の異なる 5 年生と 6 年生は分けて計画されることが望ましいと思い ます。

次に，教材の選定について，現在使用している ものを紹介します。助産婦学校で実習用に使用し ている人形を使っていますが,たいへん好評です。
実物に近い人形は,子どもたちに親近感をもたせ， 講義の後で抱かせてほしいと希望する子どもたち が必ず数人はいます。首をぐらつかせ， 4 か月ぐ らいまでは首が座らず大人は首を支え大切に抱い ていることなどを話すと, 一同驚きの表情を見せ ます。日ごろ, 助産婦学生を相手にしている私に とっては, 内容や言葉遣いにも自信がなく, いつ も緊張していますが，40分や50分の話を子どもた ちは，実に感性豊かにとらえてくれます。

子どもの感想を紹介します。

-人形を見た感想；自分の赤ちゃんの頃はあんな

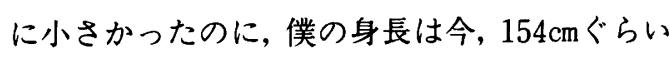
で約 3 倍ぐらいまで大きくなるのに，お母さん やお父さんが助けてくれたことにおどろき，そ して，お父さんやお母さんが大変きつかったこ とが一時頭から離れませんでした。(小 5 ・男子) ・お母さが僕を生む時, 一生慗命頑張ってこの 世界に出してくれてありがとうといいたいで す。今は,もんくとかいっぱい言っているので, あんまりもんくをいわないようにしたいです。

表 1 小学校 $5 \cdot 6$ 年生に対する指草内容

\begin{tabular}{|c|c|c|}
\hline \multicolumn{3}{|c|}{ 対象: $5 \cdot 6$ 年生男女 } \\
\hline 内 & 留 & 教 \\
\hline $\begin{array}{l}\text { わたしの誕生 } \\
\text { わたしはどうして生まれたのでしょう } \\
\text { 生命のもとは精子と卯子の結合 }\end{array}$ & $\begin{array}{l}\text { 自分の誕生に感謝と誇りをむたせ, 自分や生 } \\
\text { 命を尊重することを強調する } \\
\text { 好娠・出産時の父母の喜びや感動はドラマチ } \\
\text { ックに話す }\end{array}$ & $\begin{array}{l}\text { ベビー模型 } \\
\text { 男の子, 女の子 } \\
\text { ビデオ } \\
\text { 「弟たちの誕生」 }\end{array}$ \\
\hline $\begin{array}{l}\text { 男の子と女の子の成長の遣い } \\
\text { 男女の体は発育に伴って变化し, 男女の特徵 } \\
\text { がはっきりしてくる }\end{array}$ & $\begin{array}{l}\text { 性差を理解させる } \\
\text { それぞれの第二次性徵について知り，お互い } \\
\text { に思いやる気持ちをもつこと。 } \\
\text { 相手の嫌がることをしないことを強調 }\end{array}$ & \\
\hline \multicolumn{3}{|l|}{$\begin{array}{l}\text { 成長の個人差 } \\
\text { この時期は, 個人によって连いがあること }\end{array}$} \\
\hline $\begin{array}{l}\text { 危険な誘惑 } \\
\text { 性被害が起こるわけを話し，性被害から自分 } \\
\text { を守ること }\end{array}$ & $\begin{array}{l}\text { 子どもの性被害が多いことから, 性被害にあ } \\
\text { わないように }\end{array}$ & \\
\hline $\begin{array}{l}\text { これから成長していくために } \\
\text { 身体の清挲, 友達を大切に, 自分を大切に, } \\
\text { 男女が協力し合う }\end{array}$ & $\begin{array}{l}\text { 身体の清潔 } \\
\text { 入浴のマナー } \\
\text { 下着の取り換え }\end{array}$ & \\
\hline
\end{tabular}

内容は, 時間によって多少変更します。 
あんなに小さかった僕がこんなに大きくなった のは，お母さんたちのおかげだと思った。だか ら，この大切な体をわるくならないように夕バ コやシンナーをすわない。家のおへその緒をみ ると,お母んと僕の体は栄養でつながってい たんだなあと思った。お母さんにもらったこの 命を大切にしようと思った。(小 5 ・男子)

・小学校からダイエットをしてはいけない話をき きました。ダイエットをしようと思っていたけ どやめました。○○先生の教えてくれないこと も教えてもらって勉強になりました。(小 6 ・女 子)

・私, 成長が早いからみんなとちがうといつも思 っていた。先生の話を聞いてちょっと安心した。 みんな個人差があるから，気にしないで自分の 体を守ろう。赤ちゃんを産んだ時の喜びは産ん だことのある人でないとわからないと先生が言 ったが,でもなんとなくわかるような気がする。 お母さんは，私が生まれるまで害のあるものを さけて，大切に育ててくれたんだなあ。家に帰 っててれくさかったけど,「私を生んでくれてあ りがとう」と一言つぶやいた。(小 6 ・女子)

・11月21日，○○先生という赤ちゃんを生ませる 先生が学校にきました。そして，10時から40分 間話をしてくれました。先生は楽しく面白い先 生でした。先生の話をきいていると, 全然退屈 じゃありませんでした。そして, 赤ちゃんの話 をいろいろ話してくれました。先生が連れてき た太郎ちゃんを使って話してくれました。赤ち やんは生まれたばかりの体重は, 3000クラム, 身長は $50 \mathrm{~cm}$ 位だそうです。それから赤ちゃんは お母さんのおなかの中でどんなふうにしている とか話してくれました。生まれたばかりの赤ち やんは首がぐらぐらしているということは, ぜ んぜん知りませんでした。それと, 小さい時シ ンナーやたばこを吸ったりしたら，生んだ赤ち やんが小さいということははじめて知りまし た。先生の話はとても勉強になりました。(小 5 -女子)

\section{2. 中学生に対する指望内容}

中学生は, 思春期のスパートと呼ばれるような 発育速度の増加がみられる時期です。このように, 性的な機能が発達し, 肉体的な面で生殖能力が具
備されるとともに，人間関係が多様化する時期で もあります。そして，異性に対する関心も高まっ てきます。また，社会面では，高校入試の重圧に 大きなストレスをもちつつ学校生活を過ごしてい ます。中学校では, 高校入試の合格率に頭を痛め ているほど, 生徒たち個々の発達課題達成に向け てのかかわりがもたれているだろうかと疑問に思 います。

数少ない体験からこのようなことを申し上げる のはおしかりを受けるかもしれませんが，女子中 学生の妊娠の実態や相談内容などからみて, 中学 校における性教育のあり方に疑問をもたざるをえ ません。某中学校の教師は, 「中学時代は進学のこ とで性教育どころではない」と話していました。 今坂は, 中学教師の $91 \%$ は性教育が必要であると し，必要でないとするものは $7 \%$ \%゙ったと報告 しています。

文部省は, 「生徒指導における性に関する指導, 中学校・高等学校編」で次のように述べています。 「学校は全ての生徒に対して人間の性に関する基 礎的・基本的事項を正しく理解させ, 自己の性に 対する認識をより確かにさせるとともに人間尊 重, 男女平等の精神に基づき, 男女の人間関係や 現在及び将来の生活における性に関する諸問題に 対して, 適切な意思決定や行動の選択ができるよ うに性に関する指導を充実することが必要です」。

このように，立派な精神を基盤とした指導要領 があり, 教師の $90 \%$ 上上が必要性を感じているに もかかわらず, 性教育の時間がとれないというの が現実の中学校の姿かもしれません。性教育は当 然のことながら人間教育であり, 性教育としての 時間をとらなくても，いろいろな科目の中で展開 できるでしょう。しかし，現実に自分のからだの 変化に恼み, 戸惑い, 異性への関心に対する不安 や罪悪感をもつ生徒たちの問題をどう解決すれば いいのでしょうか。精神的に未熟な中学生の発達 課題をいまこの時期に解決していかなければ，次 のステップに進めないのではないかと思います。

次に，中学生に性交を教えるべきか否かという 論議は, いずれの場所でも行われていますが, い つも賛否両論半々ぐらいの割合です。一方, コミ ック漫画やアダルトビデオなどは女性を性の道具 として扱ったり, 性交と妊娠とは関係のないよう 
な扱いであったり，子どもたちに正しい情報が伝 わるような表現は，まったくといってよいほどな いのです。このような情報があふれている中で生 活している子どもたちに, 正しい知識を与えるこ とはほんとうに必要ないのでしょうか。

大人たちがもっと真剣に考える時期だと考えま す。私は，講演の中で性交について話すことにし ています。初めはざわめき，うつむき，目をそら していた子どもたちが, だんだん真剣な表情に変 わっていきます。従来, 性交は種族保存のみが強 調されて扱われてきましたが, 最近は連帯性や快 楽的側面からも扱われるようになっています。私 自身は, 助産婦の立場からどうしても生殖の側面 を強調してしまいますが, 性交体験の低年路化, 中学生の男女交際のあり方に対する意識をみると き，もう寝た子を起こすなという消極的な姿勢で は, 問題は解決しないと思います。

昭和60年, 某病院において, 19歳未満で出産し た19名について調查した結果, 今回の出産以前に 人工妊娠中絶の経験のあるものが 7 名 $(36.8 \%)$ いました。人工妊娠中絶や出産により将来設計を 中断せざるをえなくなった事例もあります。性教
育ではなく, 生命教育こそが必要であると発言し た作家がいましたが, 私は性教育と生命教育は別 なものとは考えられません。生命を大切にするこ とこそが性教育だと考えるからです。年々増加し ている10代の妊娠, そして人工妊娠中絶の実態を みるとき, 避妊教育もまた避けて通れないことだ と思います。

私は, 中・高校生たちの性交を肯定するもので はありません。避妊教育は人間の一生にとってき わめて大切なことであるという認識の上に立っ て，単に避妊という方法論だけでなく，人間教育 を基盤とした展開を心がけています。しかし，短 い時間でしかも，人間関係が成立していない中で の特別講演という型では, なかなか難しいことを 痛感しています。

中学生に対する指導内容は表 2 に示しました。 中学校で話す機会はきわめて少なく, 年 2 回程度 であることから内容の検討までには至っていませ ん。感想文や相談が寄せられれば別ですが, フォ ローができないのが現状です。そのために，疑問 や個人的な相談等を受けるために, 必ず自宅の電 話番号を知らせています。

表 2 中学生に対する指迸内容

\begin{tabular}{|c|c|c|}
\hline \multicolumn{3}{|c|}{ 対象: 中学 2 年生男女 } \\
\hline 内 & 留 意 点 & 教 \\
\hline $\begin{array}{l}\text { 性とは何か } \\
\text { 生命の誕生 }\end{array}$ & $\begin{array}{l}\text { いのち, 性交 } \\
\text { 生命誕生の仕組みと自分の誕生を考える }\end{array}$ & $\begin{array}{l}\text { ベビー模型 } \\
\text { 男の子, 女の子 }\end{array}$ \\
\hline $\begin{array}{l}\text { 思春期の体の変化 } \\
\text { ホルモン } \\
\text { 男子の体の変化 } \\
\text { 女子の体の変化 }\end{array}$ & $\begin{array}{l}\text { なぜ, 体の変化が起こるのか, 体の仕組みと } \\
\text { 第二次性徵, 体の成長には個人差があること } \\
\text { と, 成長の途中にあることを強調する }\end{array}$ & \\
\hline $\begin{array}{l}\text { 思春期の心の变化 } \\
\text { 男子の心の変化 } \\
\text { 女子の心の変化 }\end{array}$ & $\begin{array}{l}\text { 心の変化の特徽 } \\
\text { 男女の心の变化の特徴 }\end{array}$ & \\
\hline $\begin{array}{l}\text { 男女交際のあり方 } \\
\text { 将来のある若者が, どのような男女のつきあ } \\
\text { い方をするのが望ましいか }\end{array}$ & $\begin{array}{l}\text { 男女交際のあり方 } \\
\text { 身近な例を挙げて話す }\end{array}$ & \\
\hline 避妊について & $\begin{array}{l}\text { 受胎調節とは } \\
\text { 人工妊娠中絶 }\end{array}$ & $\begin{array}{l}\text { 模型（受胎調節避 } \\
\text { 姡具一式） }\end{array}$ \\
\hline
\end{tabular}

内容は，時間によって多少变更します。 


\section{3. 高校生に対する指迹内容}

高校では，中学で性教育を受けたことのない生 徒が多いことから，中学での指導内容とほとんど 重複しています。この時期の子どもたちの悩みは, 男女共に性器の形や大きさが第 1 位を占めます。

男子の性器の恼みは一般に報告されているよう に, ペニスの長さや大きさが 1 位であり, 次いで 包茎です。これまで男子の性器に対する悩みにつ いては相談を受けてきましたが，最近は女子から の相談が多くみられます。

最も多いのは, 外陰部の形, 特に小陰唇の大き さや形・色などです。学校では第二次性徵につい て，一般的なことは聞いているが具体的な話は聞 いていないそうです。写真があれば送ってほしい と希望する生徒もあります。小陰唇の大きさ・形・ 色などについては，できるだけ具体的に話してい ます。次いで多いのは, 月経に対する心配や不安 です。月経周期が正常であるにもかかわらず，異 常である思っている者が半数を占めます。月経の 手当てについては，小学生の時すでに教わってい るが，月経や排卵のメカニズムや思春期の特徴に
ついては，あまり具体的に聞いていないという者 が多く，助産婦の立場から具体的に話す必要性を 感じます。

男女交際については，高校生は中学生よりいつ そう異性に興味をもつ時期であり，好きだから， 愛しているからキスや性交涉をもちたい，などの 悩みを訴えてきます。なかには，大人の私には「危 ない」と叫んでしまいそうな相談の手紙もありま す。このように相談内容をみると，男子と女子の 性行動の違いなども強調する必要性を感じます。

某高等学校において, 男子103名, 女子81名を対 象にした結果を見ると，排卵や月経周期について の正解率は女子 $32 \%$, 男子 $40.9 \%$ で，男子のほう が正解率が高く，自分の身体に起こる変化を女子 は当然知っているものと思っていましたが，男子 よりも正解率が低いのは意外でした。また，もし 妊娠したら（させたら）どうするかについては, 男女差はなく，80\%が人工妊娠中絶をすると答え ていました。学業中の高校生であるから当然とい えば当然ですが，少し驚きました。避妊法につい

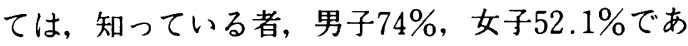

表 3 高校生に対する指䁚内容

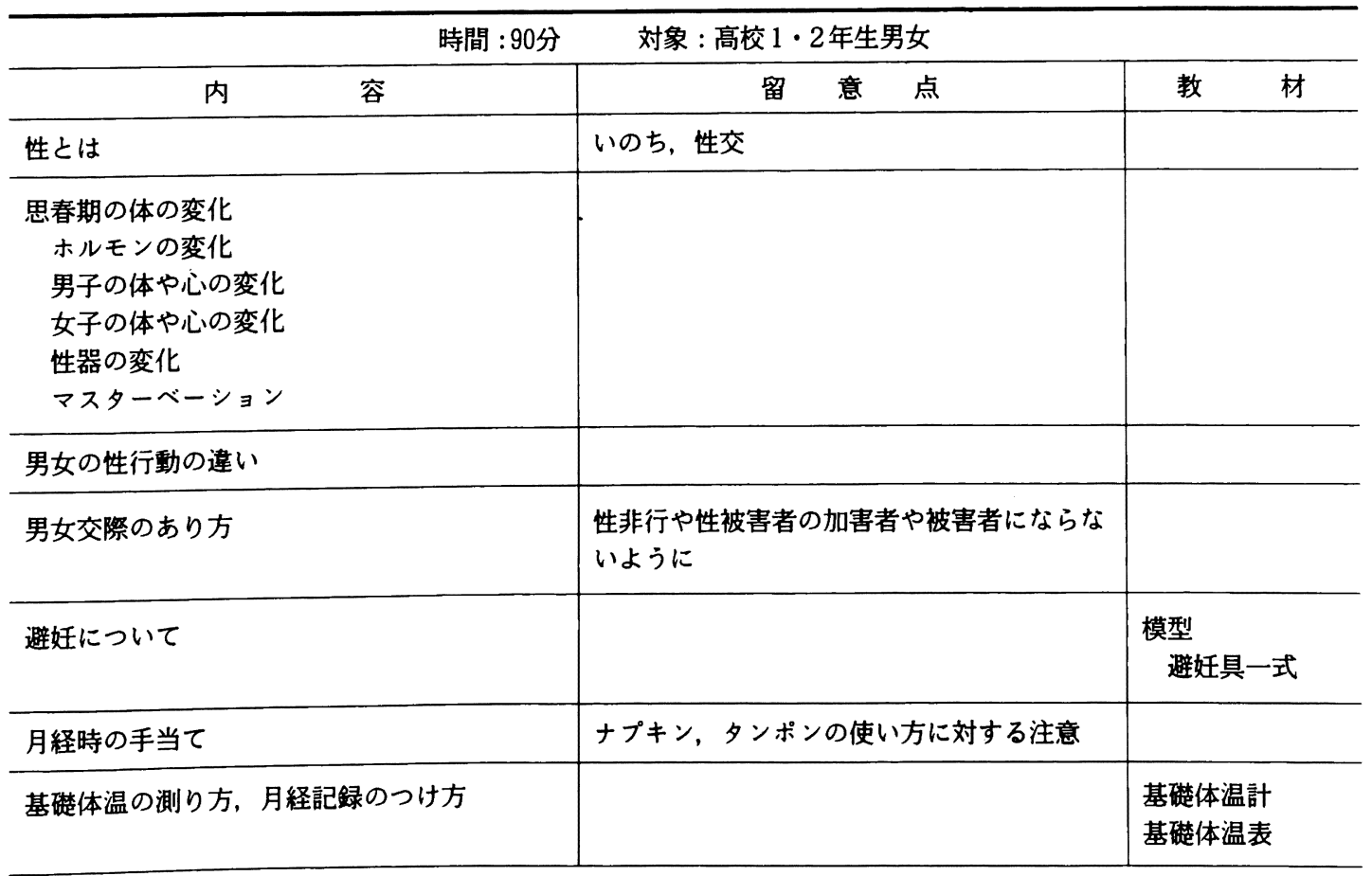

内容は，時間によって多少変更します。 
ク, 情報源は雑誌, 友人がほとんどでした。これ らの結果からみても, 高校における避妊教育は必 要だと思います。正しい知識をもたせることは, 長い将来にわたって非常に大切なことだと考えま す。

避妊教育のあとの男子学生の感想を紹介します と,「僕は, セックスについて自分自身で責任を負 えるようになるまで我慢しようと思う。女の人に とってセックスはとても大切なことなので, 男の 勝手な欲望のために女の一生をだめにするような ことのないように心がけたい」，女子学生は「コン ドームは $100 \%$ 避妊法ではないと聞いたとき，あ れがいちばん大丈夫だと思っていたので警いた」 と書いています。

人工妊娠中絶の危険性を話す場合, あまり違和 感や恐怖感をもたせる話をしてはならないことを 体験しました。中絶時に使う器械を持参して説明 している途中， 3 人の生徒が真っ青になって退場 してしまいました。決して脅しのつもりではなか ったのですが, 結果的には恐怖感をもたせること になりました。このような話をするときは, 慎重 でなければならないことを学びました。女子学生 には, 健康教育として基礎体温の測り方, 月経記 録のつけ方も指導しておく必要があり，生徒たち は測ってみたいと興味をもつ者が多くみられま す。試行錯誤で進めている性教育ではあります が, 実際に生徒たちと触れ合うことで問題も見え, また勉強不足を感じます。高校生に対する指導内 容は表 3 に示しました。

\section{4. 中高年に対する指恶内容}

わが国では，長い間中高年の性に対する話は夕 ブー視されてきました。家庭教育学級で少し中高 年の性に触れたことで，急に講演依頼が増えまし た。とはいえ, 初めから性の話を切り出すことは 私自身抵抗があり, 次のような順序で話を進めて います。

1.中高年とは

2 . 更年期障害

3. 婦人科関連の病気

4. 男性に起こりやすい病気

5 .中高年の栄養

6. 中高年の性

中高年の性の問題は, 女性では, 性欲はあるが
胵が痛いので応じたくない, 性欲はあるがこの年 になって自分の口からはいえない，など古き時代 を生きてきた女性の本音を聞くことができまし た。男性では，妻が応しててれない，寂しい，で きればセックスフレンドがほしい，等がおもなも のでした。哚刻な性の悩みをもって県外から訪れ る人もありますが, ほとんどが若い時代からの夫 婦関係の貧しさに起因することが多いようです。 一般的に知られていないリュブゼリ一等も紹介 しますが, 効果についてはまだ把握してはいませ ん。

これからは, カウンセラーとしての役割も求め られているように思います。老婦人にとっては， かつて自分たちの身近にいた助産婦（産婆）とい う存在は身近に感じられたのかも知れません。相 談する人が産婆さんでよかったといわれたとき， もっと助産婦を PR しなければならないと痛感し ました。

\section{5. 父母に対しての指迹内容}

父母に対しての指導内容は下記のとおりです。 内容については, 紙面の都合で割愛しますが, こ こは最も助産婦としての経験が生々と語れるとこ ろだと思います。個人個人がいろいろな味つけを して，その人らしさで展開できるのではないでし ようか。

\section{父母に対しての指導内容}

1. 性教育とは「どんな」教育でしょうか。 性教育とは人間教育であり，その基本は「い のち」を学ぶことである。

・すべての子どもは, 望まれて生まれなければ ならない。

・性の差別をしていませんか。

2. 性教育は「いつ」から始めたらよいのでしょ うか。

・性教育は，母親の胎内から始まっています。

・性教育は, 両親の生活の反映です（人間性を 豊かにする女性観, 男性観)。

・子どもは寂しいのです。温かい家庭を求めて います。

3. 性教育は「どこで」するのでしょうか。 家庭, 学校, 社会の責任です。

・家庭における性教育 
・社会における性教育

・学校における性教育

4. 性教育は「だれが」教えたらよいのでしょう 力。

5.性教育は「何を」教えたらよいのでしょうか。

6. 性教育は「どのように」行ったらよいのでし ょうか。

\section{III 現状の反省とこれからの性教育}

試行錯誤で進めてきた15年間の実践報告をい たしましたが，どのようなカリキュラムがいいの か, 何が必要なのか, 教材は何を使之ば効果的な のか, まだまだ課題があります。

これからの性教育は, (1)小児期, 思春期をいか に過ごすかが，その人の一生に大きな影響を及ほ すことを考えるとき，人としての生き方を基盤と

して性教育が必要であると考えます。(2)性に関す
る相談の空口が少なく，またどこにどのような場 所があるのか, どんな人がいるのか, 把握できな い現状です。そして思春期に関する相談空口の場 所をつくる必要があると考えます。(3)相談者の育 成。(4)助産婦の専門性を生かした研鑽の必要性な どが急務であると考えます。

私たちの先輩や同僚が地域に根ざした性教育活 動を実践されていますが,これからは個人の経験 としてだけではなく，チームで対応するネットワ 一クづくりをすることが必要だと思います。助産 婦は、助産婦業務の拡大や進展についての提言を するだけでなく，専門性を生かした独自性をもっ た性教育を実践することが，いま求められている と思います。

座長の労をおとりいただいた次期会長の藤田八 千代先生に心からお礼申し上げます。ご静聴あり がとうございました。 